\title{
Tumor Results Measurement Date
}

National Cancer Institute

\section{Source}

National Cancer Institute. Tumor Results Measurement Date. NCI Thesaurus. Code C162180.

The date of the tumor scan, image, or physical exam. 